\title{
Empirical relationship of tsunami height between offshore and coastal stations
}

\author{
Yutaka Hayashi \\ Seismology and Volcanology Research Department, Meteorological Research Institute, 1-1, Nagamine, Tsukuba 305-0052, Japan
}

(Received July 1, 2009; Revised October 1, 2009; Accepted November 11, 2009; Online published March 4, 2010)

\begin{abstract}
This study compares tsunami height data obtained by coastal tidal stations and offshore wave stations of the Nationwide Ocean Wave information network for Ports and HArbourS (NOWPHAS) with data obtained from real-time kinematic global positioning system (RTK-GPS) buoys. NOWPHAS wave stations and RTK-GPS buoys are typically installed off the coast - the former within several kilometers of the coast and the latter 2$20 \mathrm{~km}$ offshore. The ratio of initial tsunami height observed at a coastal tidal station to that observed at an offshore station was found to be approximately proportional to the fourth root of the ratio of the sea-bottom depths to the mean sea level at the respective offshore and coastal station. This approximation can also be applied to maximum tsunami amplitudes. The relationship derived in this paper will enable the initial tsunami height to be forecast by real-time applications using detected tsunami initial height from offshore stations, such as the sea-bottom pressure gauges of NOWPHAS stations and RTK-GPS buoys.
\end{abstract}

Key words: Green's law, NOWPHAS, real-time tsunami forecast, RTK-GPS buoy.

\section{Introduction}

Although "tsunami" etymologically means "harbor wave", there have been many occasions in the very recent past to observe tsunamis outside harbors. In the coastal waters off Japan, such opportunities have been made possible through the use of cabled ocean-bottom pressure gauges in the deep ocean (e.g., Seismology and Volcanology Research Division, Meteorological Research Institute, 1980), wave stations of the Nationwide Ocean Wave information network for Ports and HArbourS (NOWPHAS) (e.g., Nagai, 1998), and real-time kinematic global positioning system (RTK-GPS) buoys (e.g., Kato et al., 2000). NOWPHAS has recently incorporated six RTK-GPS buoy observatories into its network, but these have not yet detected a tsunami. Consequently, in this paper, "NOWPHAS wave station" indicates a wave station equipped with a sensors other than a GPS buoy. Tsunamis in the open ocean can potentially be detected both by buoys of the U.S. Deep-ocean Assessment and Reporting of Tsunamis (DART) array (e.g., González et al., 2005) and by altimeters installed on satellites (e.g., Okal et al., 1999; Gower, 2005).

At the present time, a tsunami early warning issued by the Japan Meteorological Agency (JMA; Tatehata, 1997) is based on the seismic information available just after an earthquake and the pre-computed tsunami scenario database. However, it is believed that the accuracy of tsunami prediction may be significantly improved if tsunami early warnings could utilize real-time offshore tsunami observation data (e.g. Tsushima et al., 2009). Such an improvement could potentially contribute to tsunami dis-

Copyright (c) The Society of Geomagnetism and Earth, Planetary and Space Sciences (SGEPSS); The Seismological Society of Japan; The Volcanological Society of Japan; The Geodetic Society of Japan; The Japanese Society for Planetary Sciences; TERRAPUB.

doi:10.5047/eps.2009.11.006 aster mitigation.

Within this framework, in 2009, the Headquarters for Earthquake Research Promotion (HERP), a special governmental organization of Japan, drew up the report entitled "The next Promotion of Earthquake ResearchComprehensive Basic Policies for the Promotion of Earthquake Research through the Observation, Survey, and Research" (HERP, 2009). This report establishes "Upgrading tsunami prediction technology by real-time utilization of sea-area tsunami data and/or sophisticated tsunami source modeling" as one of the basic earthquake research targets to be addressed in the upcoming 10 years.

The first essential step towards realizing tsunami realtime forecasting based on offshore observations of propagating tsunamis - and not by seismic observations-is to determine the basic relationship between tsunami height observed at offshore observatories and that observed at coastal observatories. The relationship between observation data obtained by cabled ocean-bottom pressure sensors, which are installed in the deep ocean several tens of kilometers from the coast, and those obtained by coastal tidal stations, all belonging to the offshore observation networks mentioned above, has already been discussed. Baba et al. (2004) derived the equation describing the relationship between tsunami height at these two locations from Green's law through theoretical considerations. That is

$$
H_{\mathrm{c}}=2 H_{\mathrm{o}} h_{\mathrm{o}}^{1 / 4}
$$

where $H_{\mathrm{c}}$ is the corrected initial tsunami height or maximum tsunami amplitude, $H_{\mathrm{o}}$ is the observed initial tsunami height or maximum tsunami amplitude at an offshore site, $h_{\mathrm{o}}$ is the water depth at an offshore site, and the coastline water depth is implicitly assumed to be $1 \mathrm{~m}$. Takayama (2008) derived a set of empirical formulas for any combination of a cabled ocean-bottom pressure gauge (OBPG) and 

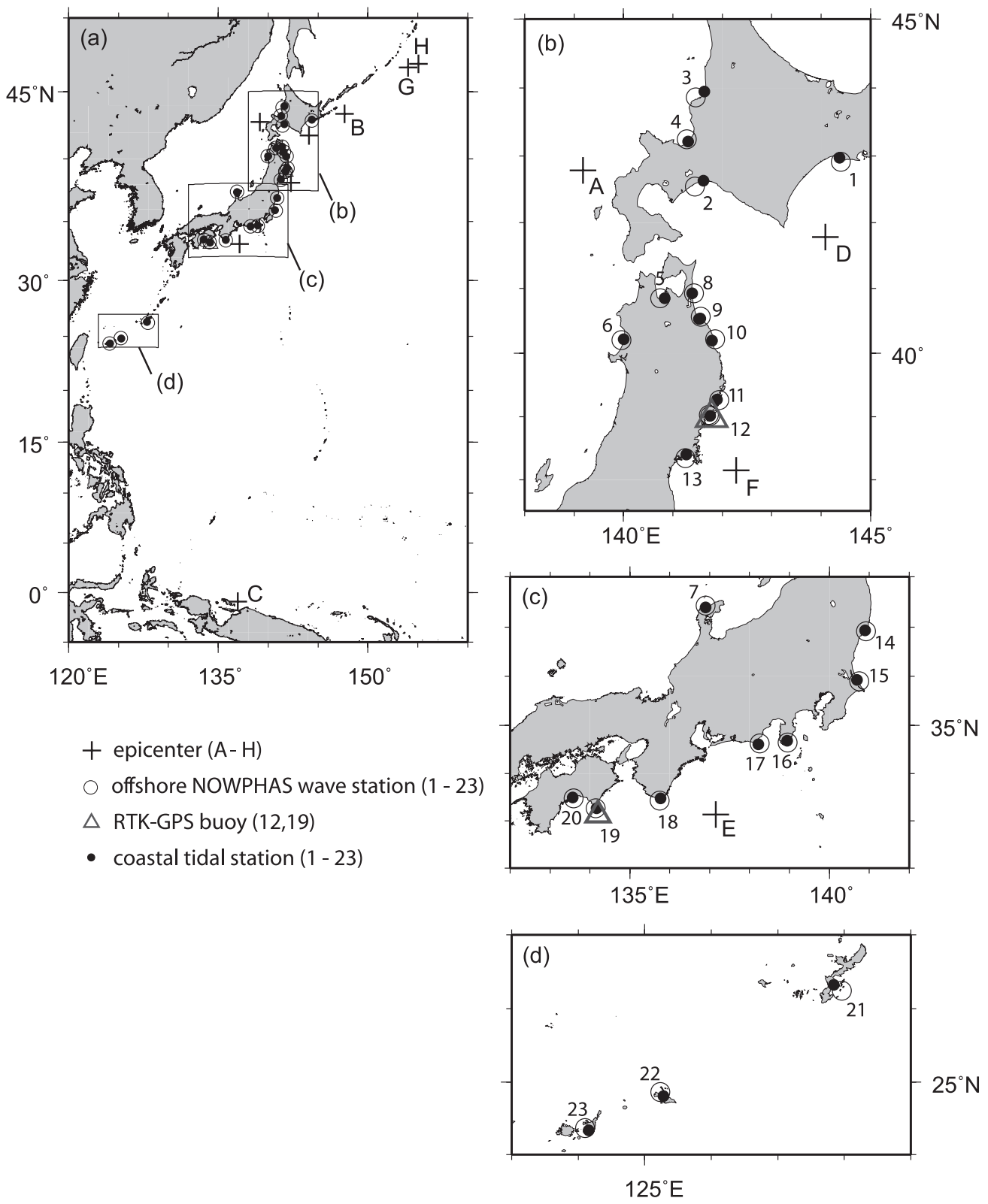

Fig. 1. Location maps of stations and epicenters. More information on each station and each epicenter is available in Tables 1 and 2, respectively.

a coastal tidal station. Each formula derived for a certain combination of OBPGs and coastal tidal station has correction term(s) of epicentral distances and/or tsunami amplitude. This set of formulas can be understood as the extension of Eq. (1) derived by Baba et al. (2004). However, basic relationships of tsunami height between NOWPHAS wave stations or RTK-GPS buoys and coastal tidal stations has not yet been studied.

RTK-GPS buoys, which are installed $2-20 \mathrm{~km}$ off the coast of Japan, have only sampled two tsunami events to date for which the clarity of the data was sufficient data for use in assessing tsunami height: the 2003 Tokachi-oki earthquake tsunami (Nagai and Ogawa, 2004) and the 2004 earthquake tsunami off the Kii peninsula (Kato et al., 2005; Nagai and Satomi, 2005). Due to this limited amount of data and sampled tsunami events, it is therefore impossible to directly discuss the relationship between observed tsunami height as recorded by the RTK-GPS buoys and coastal tidal gauges. In contrast, NOWPHAS wave stations have recorded a significant amount of tsunami data since Takayama et al. (1994) first reported the detection of a tsunami using data from these stations - the 1993 southwest Hokkaido earthquake tsunami. However, no general formula between offshore tsunami observation data acquired by NOWPHAS wave stations and those acquired by coastal tidal stations has been developed.

Here, we present a formula explaining the relationship between tsunami height data recorded by offshore NOWPHAS wave stations or RTK-GPS buoys and coastal tidal stations in Japan.

\section{Offshore and Coastal Tsunami Data}

For this study, data on initial tsunami heights and maximum tsunami amplitudes recorded by pairs of offshore wave stations and tidal stations; each offshore wave station and matching tidal station was within $20 \mathrm{~km}$ of each other. 
Table 1. Offshore and coastal observatories.

\begin{tabular}{|c|c|c|c|c|c|c|}
\hline $\begin{array}{c}\text { pair } \\
\text { no. }\end{array}$ & $\begin{array}{c}\text { flag } \\
* 1\end{array}$ & $\begin{array}{c}\text { name } \\
* 2\end{array}$ & $\begin{array}{c}\text { location } \\
\text { longitude }\end{array}$ & latitude & $\begin{array}{l}\text { depth } \\
(\mathrm{m}) * 3\end{array}$ & $\begin{array}{c}\text { operating organization } \\
{ }^{*} 4\end{array}$ \\
\hline \multirow[t]{2}{*}{1} & 0 & Off Kushiro & $42^{\circ} 54^{\prime} 38^{\prime \prime} \mathrm{N}$ & $144^{\circ} 23^{\prime} 50^{\prime \prime} \mathrm{E}$ & 50.1 & Hokkaido RDB \\
\hline & C & Kushiro & $42^{\circ} 58^{\prime} 29^{\prime \prime}$ & $144^{\circ} 22^{\prime} 16^{\prime \prime}$ & 3.8 & JMA \\
\hline \multirow[t]{2}{*}{2} & 0 & Off Tomakomai H. & $42^{\circ} 32^{\prime} 39^{\prime \prime}$ & $141^{\circ} 26^{\prime} 46^{\prime \prime}$ & 50.7 & Hokkaido RDB \\
\hline & C & Tomakomai W H. & $42^{\circ} 37^{\prime} 47^{\prime \prime}$ & $141^{\circ} 37^{\prime} 16^{\prime \prime}$ & 3.8 & Hokkaido RDB \\
\hline \multirow[t]{2}{*}{3} & 0 & Off Rumoi H. & $43^{\circ} 51^{\prime} 59^{\prime \prime}$ & $141^{\circ} 28^{\prime} 07^{\prime \prime}$ & 49.8 & Hokkaido RDB \\
\hline & C & Rumoi & $43^{\circ} 57^{\prime} 02^{\prime \prime}$ & $141^{\circ} 38^{\prime} 06^{\prime \prime}$ & 5.8 & Hokkaido RDB \\
\hline \multirow[t]{2}{*}{4} & 0 & Off Ishikari New H. & $43^{\circ} 14^{\prime} 55^{\prime \prime}$ & $141^{\circ} 16^{\prime} 44^{\prime \prime}$ & 22.4 & Hokkaido RDB \\
\hline & $\mathrm{C}$ & Ishikari New H. & $43^{\circ} 12^{\prime} 56^{\prime \prime}$ & $141^{\circ} 18^{\prime} 26^{\prime \prime}$ & 2.9 & Hokkaido RDB \\
\hline \multirow[t]{2}{*}{5} & 0 & Off Aomori & $40^{\circ} 51^{\prime} 00^{\prime \prime}$ & $140^{\circ} 44^{\prime} 32^{\prime \prime}$ & 21.8 & Tohoku RDB \\
\hline & C & Aomori & $40^{\circ} 50^{\prime} 10^{\prime \prime}$ & $140^{\circ} 45^{\prime} 47^{\prime \prime}$ & 4.8 & Tohoku RDB \\
\hline \multirow[t]{2}{*}{6} & 0 & Off Noshiro H. & $40^{\circ} 12^{\prime} 06^{\prime \prime}$ & $139^{\circ} 57^{\prime} 23^{\prime \prime}$ & 25.5 & Akita Prefecture \\
\hline & $\mathrm{C}$ & Noshiro & $40^{\circ} 12^{\prime} 50^{\prime \prime}$ & $140^{\circ} 00^{\prime} 14^{\prime \prime}$ & 8.7 & Akita Prefecture \\
\hline \multirow[t]{2}{*}{7} & 0 & Off Wajima H. & $37^{\circ} 25^{\prime} 51^{\prime \prime}$ & $136^{\circ} 54^{\prime} 08^{\prime \prime}$ & 50.0 & Hokuriku RDB \\
\hline & $\mathrm{C}$ & Wajima & $37^{\circ} 23^{\prime} 51^{\prime \prime}$ & $136^{\circ} 54^{\prime} 10^{\prime \prime}$ & 1.7 & Hokuriku RDB \\
\hline \multirow[t]{2}{*}{8} & 0 & Off Mutsu-Ogawara H. & $40^{\circ} 55^{\prime} 30^{\prime \prime}$ & $141^{\circ} 25^{\prime} 27^{\prime \prime}$ & 49.0 & Tohoku RDB \\
\hline & C & Mutsu-Ogawara & $40^{\circ} 55^{\prime} 35^{\prime \prime}$ & $141^{\circ} 23^{\prime} 17^{\prime \prime}$ & 6.0 & Tohoku RDB \\
\hline 9 & 0 & Off Hachinohe H. & $40^{\circ} 33^{\prime} 39^{\prime \prime}$ & $141^{\circ} 34^{\prime} 06^{\prime \prime}$ & 27.7 & Tohoku RDB \\
\hline$-a$ & $\mathrm{C}$ & Hachinohe-Shinminato & $40^{\circ} 31^{\prime} 54^{\prime \prime}$ & $141^{\circ} 31^{\prime} 40^{\prime \prime}$ & 6.7 & JMA \\
\hline$-b$ & C & Hachinohe-Same & $40^{\circ} 32^{\prime} 06^{\prime \prime}$ & $141^{\circ} 33^{\prime} 22^{\prime \prime}$ & 3.2 & Tohoku RDB \\
\hline \multirow[t]{2}{*}{10} & 0 & Off Kuji H. & $40^{\circ} 13^{\prime} 05^{\prime \prime}$ & $141^{\circ} 51^{\prime} 37^{\prime \prime}$ & 50.0 & Tohoku RDB \\
\hline & C & Kuji & $40^{\circ} 11 ' 32^{\prime \prime}$ & $141^{\circ} 47^{\prime} 48^{\prime \prime}$ & 5.4 & Tohoku RDB \\
\hline \multirow[t]{2}{*}{11} & 0 & Kamaishi H. & $39^{\circ} 15^{\prime} 54^{\prime \prime}$ & $141^{\circ} 56^{\prime} 06^{\prime \prime}$ & 49.8 & Tohoku RDB \\
\hline & C & Kamaishi & $39^{\circ} 16^{\prime} 24^{\prime \prime}$ & $141^{\circ} 53^{\prime} 21^{\prime \prime}$ & 5.4 & JCG \\
\hline $12-\mathrm{a}$ & 0 & Off Ofunato GPS & $39^{\circ} 00^{\prime} 36^{\prime \prime}$ & $141^{\circ} 47^{\prime} 06^{\prime \prime}$ & 53.0 & $\# 1$ \\
\hline$-b$ & 0 & Out Ofunato Bay & $39^{\circ} 00^{\prime} 52^{\prime \prime}$ & $141^{\circ} 45^{\prime} 17^{\prime \prime}$ & 16.4 & Tohoku RDB \\
\hline \multirow[t]{2}{*}{$-c$} & 0 & In Ofunato bay & $39^{\circ} 02^{\prime} 03^{\prime \prime}$ & $141^{\circ} 43^{\prime} 49^{\prime \prime}$ & 25.0 & Tohoku RDB \\
\hline & C & Ofunato & $39^{\circ} 01^{\prime} 10^{\prime \prime}$ & $141^{\circ} 45^{\prime} 13^{\prime \prime}$ & 7.2 & JMA \\
\hline 13 & 0 & Off Ishinomaki H. & $38^{\circ} 20^{\prime} 48^{\prime \prime}$ & $141^{\circ} 15^{\prime} 19^{\prime \prime}$ & 20.8 & Tohoku RDB \\
\hline & C & Ishinomaki & $38^{\circ} 24^{\prime} 19^{\prime \prime}$ & $141^{\circ} 16^{\prime} 14^{\prime \prime}$ & 7.6 & Tohoku RDB \\
\hline 14 & 0 & Off Onahama H. & $36^{\circ} 55^{\prime} 04^{\prime \prime}$ & $140^{\circ} 55^{\prime} 18^{\prime \prime}$ & 23.8 & Tohoku RDB \\
\hline & C & Onahama & $36^{\circ} 56^{\prime} 13^{\prime \prime}$ & $140^{\circ} 53^{\prime} 31^{\prime \prime}$ & 10.2 & JMA \\
\hline 15 & 0 & Off Kashima H. & $35^{\circ} 53^{\prime} 55^{\prime \prime}$ & $140^{\circ} 45^{\prime} 14^{\prime \prime}$ & 24.0 & Kanto RDB \\
\hline & C & Kashima & $35^{\circ} 55^{\prime} 46^{\prime \prime}$ & $140^{\circ} 41^{\prime} 38^{\prime \prime}$ & 5.0 & Kanto RDB \\
\hline 16 & 0 & Off Shimoda H. & $34^{\circ} 38^{\prime} 48^{\prime \prime}$ & $138^{\circ} 57^{\prime} 11^{\prime \prime}$ & 51.1 & Chubu RDB \\
\hline & C & Shimoda & $34^{\circ} 40^{\prime} 49^{\prime \prime}$ & $138^{\circ} 56^{\prime} 53^{\prime \prime}$ & 2.5 & Chubu RDB \\
\hline 17 & 0 & Off Omaezaki & $34^{\circ} 37^{\prime} 17^{\prime \prime}$ & $138^{\circ} 15^{\prime} 33^{\prime \prime}$ & 22.8 & Chubu RDB \\
\hline & C & Omaezaki & $34^{\circ} 36^{\prime} 31^{\prime \prime}$ & $138^{\circ} 13^{\prime} 19^{\prime \prime}$ & 2.7 & JMA \\
\hline 18 & 0 & Off Shionomisaki & $33^{\circ} 25^{\prime} 59^{\prime \prime}$ & $135^{\circ} 44^{\prime} 50^{\prime \prime}$ & 54.7 & Kinki RDB \\
\hline & $\mathrm{C}$ & Kushimoto & $33^{\circ} 28^{\prime} 33^{\prime \prime}$ & $135^{\circ} 46^{\prime} 24^{\prime \prime}$ & 3.1 & JMA \\
\hline $19-a$ & 0 & Off Muroto GPS & $33^{\circ} 08^{\prime} 26^{\prime \prime}$ & $134^{\circ} 12^{\prime} 10^{\prime \prime}$ & 100.0 & $\# 2$ \\
\hline$-b$ & 0 & Off Murotsu & $33^{\circ} 16^{\prime} 11^{\prime \prime}$ & $134^{\circ} 08^{\prime} 42^{\prime \prime}$ & 27.7 & Shikoku RDB \\
\hline & C & Murotomisaki & $33^{\circ} 15^{\prime} 59^{\prime \prime}$ & $134^{\circ} 09^{\prime} 52^{\prime \prime}$ & 4.2 & JMA \\
\hline 20 & 0 & Off Kochi H. & $33^{\circ} 28^{\prime} 57^{\prime \prime}$ & $133^{\circ} 35^{\prime} 13^{\prime \prime}$ & 24.1 & Shikoku RDB \\
\hline & C & Kochi & $33^{\circ} 29^{\prime} 56^{\prime \prime}$ & $133^{\circ} 34^{\prime} 09^{\prime \prime}$ & 6.2 & JMA \\
\hline 21 & 0 & Off Nakagusuku H. & $26^{\circ} 14^{\prime} 32^{\prime \prime}$ & $127^{\circ} 57^{\prime} 55^{\prime \prime}$ & 39.6 & Okinawa GB \\
\hline & C & Nakagusuku & $26^{\circ} 19^{\prime} 25^{\prime \prime}$ & $127^{\circ} 50^{\prime} 24^{\prime \prime}$ & 3.0 & Okinawa GB \\
\hline 22 & 0 & Off Hirara H. & $24^{\circ} 51^{\prime} 39^{\prime \prime}$ & $125^{\circ} 14^{\prime} 08^{\prime \prime}$ & 44.1 & Okinawa GB \\
\hline & C & Hirara & $24^{\circ} 48^{\prime} 30^{\prime \prime}$ & $125^{\circ} 16^{\prime} 46^{\prime \prime}$ & 4.0 & Okinawa GB \\
\hline 23 & 0 & Off Ishigaki H. & $24^{\circ} 21^{\prime} 55^{\prime \prime}$ & $124^{\circ} 06^{\prime} 10^{\prime \prime}$ & 39.8 & Okinawa GB \\
\hline & $\mathrm{C}$ & Ishigaki & $24^{\circ} 20^{\prime} 14^{\prime \prime}$ & $124^{\circ} 09^{\prime} 22^{\prime \prime}$ & 5.1 & JMA \\
\hline 10 & & gauge, $\mathrm{O}$ : offsho & & & & \\
\hline 21 & & GPS: RTK-GPS bu & & & & \\
\hline $\begin{array}{l}* 3 \mathrm{be} \\
\text { read }\end{array}$ & & $\begin{array}{l}\text { in sea level; For coas } \\
\text { harts are indicated (s }\end{array}$ & 3). & depths wit & (III & ach station by mean \\
\hline *4 GB & Gen & eral Bureau, Cabinet Offi & G: Japan C & t Guard & & \\
\hline JMA & Jap & in Meteorological Agency & & & & \\
\hline $\mathrm{RDB}$ & Reg & ional Developing Bureau & y of Land, I & astructure, $\mathrm{T}$ & port, an & d Tourism \\
\hline$\# 1 し$ & & Tokyo, Hitachi Zosen & & & & \\
\hline & & -okyo, Disaster Redu & ת & ation $\ln$ & 1, 1 mavion & Zosen Cc \\
\hline
\end{tabular}

Tsunami data detected by the NOWPHAS stations, which are currently operated by the Port and Airport Research Institute (PARI) and the RTK-GPS buoys were used for offshore observation data (Fig. 1; Table 1). Tsunami initial $P_{2}$ heights and maximum tsunami amplitudes at NOWPHAS wave stations and RTK-GPS buoys determined from the low-pass filtered waveforms were used. These tsunami observation data had been published in Technical Notes of the Port and Airport Research Institute. In addition to the data reported in these technical notes, we also sought coastal 
Table 2. Tsunami events.

\begin{tabular}{|c|c|c|c|c|c|c|c|}
\hline$\overline{\text { no. }}$ & date *2 & $\begin{array}{c}\text { time *2 } \\
\text { (JST) }\end{array}$ & $\begin{array}{c}\text { epicenter *2 } \\
\text { region }\end{array}$ & latitude & longitude & $\begin{array}{c}\text { flag } \\
* 1\end{array}$ & $\begin{array}{c}\text { magnitude } \\
{ }^{*} 2\end{array}$ \\
\hline $\bar{A}$ & Jul. 12, 1993 & $22 \mathrm{~h} 17 \mathrm{~m}$ & SW of Hokkaido & $42^{\circ} 47^{\prime} \mathrm{N}$ & $139^{\circ} 11^{\prime} \mathrm{E}$ & $n$ & 7.8 \\
\hline B & Oct. 4, 1994 & $22 \mathrm{~h} 22 \mathrm{~m}$ & E of Hokkaido & $43^{\circ} 23^{\prime} \mathrm{N}$ & $147^{\circ} 40^{\prime} \mathrm{E}$ & $\mathrm{n}$ & 8.1 \\
\hline C & Feb. 17, 1996 & $14 \mathrm{~h} 59 \mathrm{~m}$ & Irian Jaya, Indonesia & $00^{\circ} 54^{\prime} \mathrm{S}$ & $136^{\circ} 57^{\prime} \mathrm{E}$ & $f$ & 8.1 \\
\hline D & Sep. 26, 2003 & 04h50m & SE off Tokachi & $41^{\circ} 47^{\prime} \mathrm{N}$ & $144^{\circ} 05^{\prime} \mathrm{E}$ & $\mathrm{n}$ & 8.0 \\
\hline$E$ & Sep. 5, 2004 & $23 \mathrm{~h} 57 \mathrm{~m}$ & SE off Kii Peninsula & $33^{\circ} 08^{\prime} \mathrm{N}$ & $137^{\circ} 09^{\prime} \mathrm{E}$ & $\mathrm{n}$ & 7.4 \\
\hline $\mathrm{F}$ & Aug .16, 2005 & $11 \mathrm{~h} 46 \mathrm{~m}$ & E off Miyagi Prefecture & $38^{\circ} 09^{\prime} \mathrm{N}$ & $142^{\circ} 17^{\prime} \mathrm{E}$ & $n$ & 7.2 \\
\hline G & Nov. 15,2006 & $20 \mathrm{~h} 14 \mathrm{~m}$ & E of Kuril Island & $46^{\circ} 42^{\prime} \mathrm{N}$ & $154^{\circ} 03^{\prime} \mathrm{E}$ & $f$ & 7.9 \\
\hline $\mathrm{H}$ & Jan. 13,2007 & $13 \mathrm{~h} 23 \mathrm{~m}$ & E of Kuril Island & $46^{\circ} 56^{\prime} \mathrm{N}$ & $155^{\circ} 03^{\prime} \mathrm{E}$ & $f$ & 8.2 \\
\hline
\end{tabular}

Table 3. Observation data used for analysis. Pair numbers and event numbers are the same as in Tables 1 and 2.

\begin{tabular}{|c|c|c|c|}
\hline \multirow{2}{*}{$\begin{array}{l}\text { event } \\
\text { no. }\end{array}$} & \multicolumn{2}{|c|}{ station pairs whose data are available } & \multirow[t]{2}{*}{ references } \\
\hline & Initial height & maximum amplitude & \\
\hline A & 6,7 & none & JMA(1994), Takayama et al. (1994) \\
\hline $\mathrm{B}$ & $8,9 a, 12 b$ & $8,9 a, 12 b$ & JMA(1995), Nagai et al. (1995) \\
\hline $\mathrm{C}$ & $12 b, 15$ & $8,9 a, 15$ & JMA(1997), Kobune et al. (1996) \\
\hline $\mathrm{D}$ & $2,10,11, \mathbf{1 2 a}, 12 b, 12 c, 13,14$ & $2,9 a, 9 b, 10,11, \mathbf{1 2 a}, 12 b, 12 c, 13,14$ & JMA(2008), Nagai and Ogawa (2004) \\
\hline $\mathrm{E}$ & $17,18, \mathbf{1 9 a}, 19 b$ & $17,18, \mathbf{1 9 a}, 19 b$ & JMA(2008), Nagai and Satomi (2005) \\
\hline $\mathrm{F}$ & none & $10,11,12 b, 12 c, 13,14$ & JMA(2008), Nagai and Satomi (2006) \\
\hline G & $1,9 a, 11,13,14,15$ & $\begin{array}{l}1,2,4,5,9 a, 11,13,14 \\
15,16,17,18,19,20,21,22\end{array}$ & JMA(2008), Shimizu et al. (2007) \\
\hline $\mathrm{H}$ & $9 a$ & $1,2,9 a, 11,13,14,15,16,17,19 b$ & JMA(2008), Shimizu et al. (2007) \\
\hline
\end{tabular}

Bold numbers indicate a pair includina RTK-GPS buov station

tsunami data from Tidal Observations and The Annual Seismological Bulletin of Japan published by the JMA. Due to background noise interfering with the quality of the observation data, we did not use tsunami observation data $<5 \mathrm{~cm}$ in this study. A total of 26 sets of initial tsunami height observations and 53 sets of maximum tsunami amplitude data from eight tsunami events that occurred between 1993 and 2007 were retrieved (Fig. 1; Tables 2, 3).

\section{Experimental Equation Relating Offshore and Coastal Tsunami Height}

One equation derived from Green's law was tested to determine if it could explain the observed data on initial tsunami heights and maximum tsunami amplitudes that were retrieved as described in Section 2.

Here, $H$ is supposed to be an offshore initial tsunami height (or maximum tsunami amplitude), under the assumption of no influence by the reflected tsunami wave at coastlines. If the doubled effects of total reflection at a coastline and amplification effects due to water depth differences are considered, based on the Green's law, initial tsunami height (or maximum tsunami amplitude) at the coast should be approximated by

$$
H_{\mathrm{c}}^{*}=2 H\left(h_{\mathrm{o}} / h_{\mathrm{c}}\right)^{1 / 4},
$$

where $H_{\mathrm{c}}^{*}$ is initial tsunami height (or maximum tsunami amplitude) at the coast, $h_{\mathrm{o}}$ is the water depth at an offshore site as measured from the mean sea level, and $h_{\mathrm{c}}$ is the seabottom depth near a coastal tide gauge as measured from the mean sea level. Although an offshore tsunami is actually affected by the reflected wave, if an efficiency parameter $k$

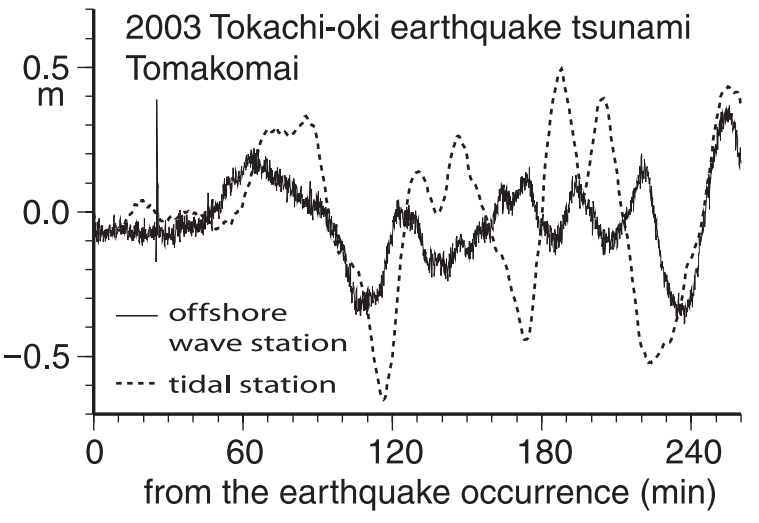

Fig. 2. An example of a pair of tsunami waveforms observed at an offshore wave station and its nearby coastal tidal station. Tsunami waveforms observed at the NOWPHAS wave station (off Tomakomai harbor), which is located $4.0 \mathrm{~km}$ from the nearest coast, and the tide gauge at west Tomakomai harbor (no. 2 in Fig. 1 and Table 1) during the 2003 Tokachi-oki earthquake tsunami (D in Fig. 1 and Table 2) are indicated. Tsunami waveform data (Nagai and Ogawa, 2004) have been downloaded from http://www.pari.go.jp/bsh/ky-skb/ kaisho/.

is introduced, the height of the initial offshore tsunami (or maximum tsunami amplitude) can be derived as

$$
H_{\mathrm{o}}=(1+k) H,
$$

where $H_{\mathrm{o}}$ is the observed height of the initial tsunami or maximum tsunami amplitude at an offshore site, and $k$ is the efficiency parameter. Equation (3) can then be used to express the ratio of additional tsunami height or amplitude caused by reflected wave. Based on these data, the equation 


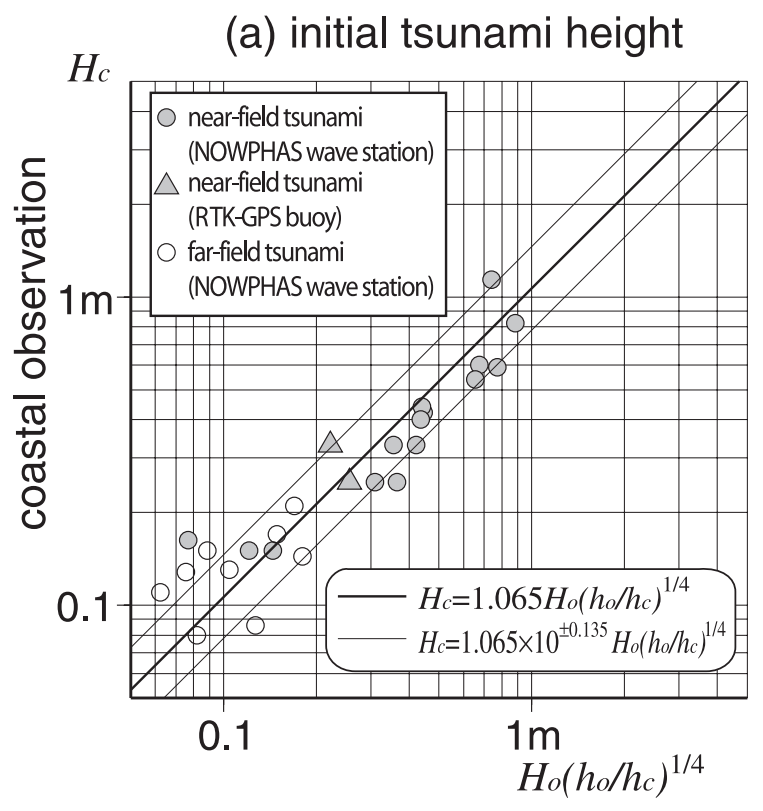

$H_{c}$

(b) maximum tsunami amplitude

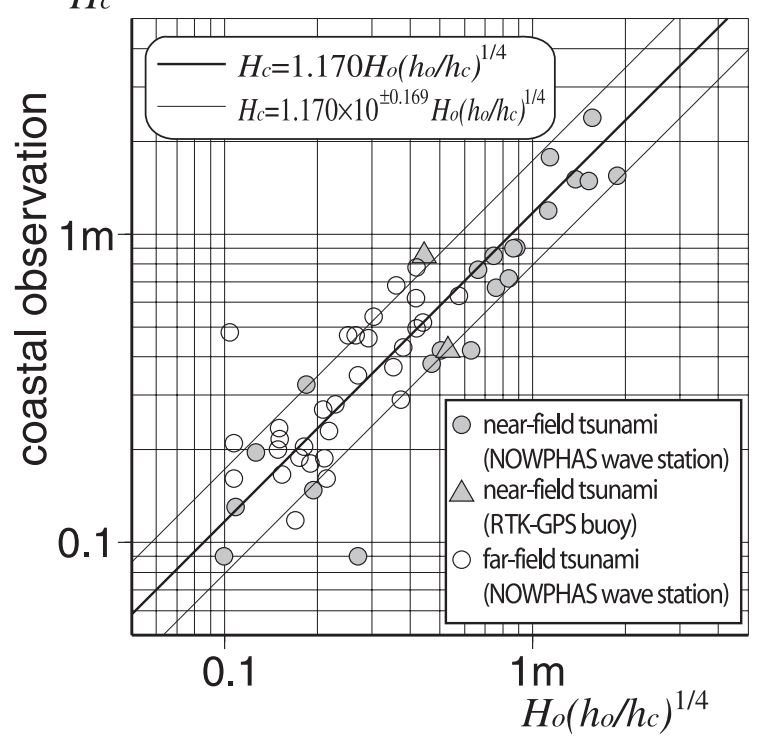

Fig. 3. Relationship between tsunami height of offshore and coastal stations. The $X$-axis indicates (a) corrected initial tsunami heights or (b) maximum tsunami amplitudes. A corrected value is defined as (a) the observed offshore initial tsunami height or (b) the maximum tsunami amplitude multiplied by the fourth root of the ratio of the water depth (Table 1) at the offshore station to that of its nearby coastal station. The $Y$-axis indicates (a) initial tsunami heights or (b) maximum tsunami amplitudes observed at coastal stations. The thick lines indicate the regression function derived by this study. The pairs of thin lines indicate the range of the single standard deviation. All pairs of data listed in Table 3 are plotted. Data are flagged near- or far-field as indicated in Table 2 .

to be tested in this paper is

$$
H_{\mathrm{c}}=\alpha H_{\mathrm{o}}\left(h_{\mathrm{o}} / h_{\mathrm{c}}\right)^{1 / 4},
$$

where $H_{\mathrm{c}}$ is the corrected height of the initial tsunami or maximum tsunami amplitude, and $\alpha$ is defined by

$$
\alpha=2 /(1+k) \text {. }
$$

Because of its definition, $-1<k<1$ should be satisfied; therefore, $\alpha>1$ is expected.
The assumption that the initial tsunami height should be partially affected by the reflected wave was based on the following evidence recorded by both an offshore NOWPHAS sea-bottom pressure gauge and a coastal tide gauge at Tomakomai (no. 2 in Fig. 1 and Table 1) located in southern Hokkaido during the 2003 Tokachi-oki earthquake tsunami (Nagai and Ogawa, 2004). As shown in Fig. 2, the crest of the initial tsunami wave at the NOWPHAS offshore wave station appeared after the arrival of tsunami recorded at the nearby coastal tide gauges.

The sea-bottom depth is obtained by reading the average water depth within a certain distance $(r)$ from a coastal tidal station along a waterway and using the largest-scaled sea charts (mostly 1:10,000) available. In this study, $r=100$ $\mathrm{m}$ is used, and the average water depth read by the charts is indicated in the Table 1.

The results of regression analysis between the tsunami observation data obtained by offshore observatories (NOWPHAS wave stations and RTK-GPS buoys) and tidal stations are summarized in Fig. 3. The derived regression lines are

$$
H_{\mathrm{c}, \text { init }}=1.065 H_{\mathrm{o}, \text { init }}\left(h_{\mathrm{o}} / h_{\mathrm{c}}\right)^{1 / 4}
$$

and

$$
H_{\mathrm{c}, \max }=1.170 H_{\mathrm{o}, \max }\left(h_{\mathrm{o}} / h_{\mathrm{c}}\right)^{1 / 4},
$$

where $H_{\mathrm{o}}$,init and $H_{\mathrm{o} \text {,max }}$ are the initial tsunami height and the maximum tsunami amplitude observed at an offshore wave station, respectively, and $H_{\mathrm{c}, \text { init }}$ and $H_{\mathrm{c} \text {, max }}$ are the initial tsunami height and the maximum tsunami amplitude at the nearby coastal tidal station estimated by the regression function, respectively. Thus, Eq. (6) properly corrects and explains the relationship between the initial tsunami height data recorded by offshore sites (NOWPHAS wave stations and RTK-GPS buoys) and those recorded by nearby coastal tidal stations, and Eq. (7) explains the maximum tsunami amplitude data in the same way.

\section{Discussion}

\subsection{Accuracy of tsunami height correction}

Proportional constants $(\alpha)$ are 1.065 for initial tsunami height and 1.170 for maximum tsunami amplitude (Eqs. (6) and (7)). The standard deviation of the log-scaled residual error of initial tsunami heights and maximum tsunami amplitudes are 0.135 and 0.169 , respectively (Fig. 3). Here, we discuss the accuracy of forecasting initial tsunami heights and maximum tsunami amplitudes at coastal tidal stations, when a tsunami at a coast is forecast by applying Eqs. (6) and (7) to offshore tsunami data.

If the range of the above-mentioned standard deviation of the log-scaled residual error is considered, the initial tsunami height at a coastal tidal station is likely to be within $10^{-0.135}(73 \%)$ to $10^{0.135}(136 \%)$ of the corrected tsunami height calculated by Eq. (6) with offshore tsunami data. If a range of twice the standard deviation is considered, then most of the initial tsunami height at a coastal tidal station can be expected to be within $54-186 \%$ of the corrected tsunami value. In the same way, if the range of the standard deviation (or twice the standard deviation) is considered, the maximum tsunami amplitudes at a coastal tidal station is likely to be within $68-148 \%$ (or $46-218 \%$ ) of the 
corrected tsunami amplitude calculated by Eq. (7) with offshore tsunami data.

Thus, the formulas derived in this paper (Eq. (6)) can correct initial tsunami height data at offshore NOWPHAS wave stations and RTK-GPS buoys so that the data can be treated in the same way as data recorded at a nearby coastal tidal station. This correction brings the difference between the two data sets to approximately $30 \%$. If the height of the offshore tsunami at these offshore observatories can be obtained in real-time, tsunami height at the nearby coasts can potentially be forecasted with equal accuracy by applying the formula derived in this paper to the obtained offshore data.

\subsection{Dependency of definition of $\boldsymbol{h}_{\mathbf{c}}$}

In Section 3, the depth at a coastal site $\left(h_{\mathrm{c}}\right)$ is defined as the average depth of the sea-bottom to mean sea level within $r(=100 \mathrm{~m})$ from the site along the waterway. However, it is not self-evident that the average depth within $100 \mathrm{~m}$ can represent the depth near the coast or that it can be applied to Eq. (4) derived from Green's law because the typical tsunami wavelength near a coast exceeds the kilometer order. In order to check whether parameter $r$, which is necessary in the definition of $h_{\mathrm{c}}$, is appropriate, the proportional constants $(\alpha)$ and standard deviations of log-scaled residual errors $(\sigma)$ are calculated by using various $r(=50$, 100, 200, 400, 600, $800 \mathrm{~m}$ ).

Figure 4(a) shows that $\alpha$ is more than 1.0 for all of the tested range and that $\alpha$ increases as $r$ increases. Therefore, $\alpha$ is the parameter dependant on $r$. On the other hand,
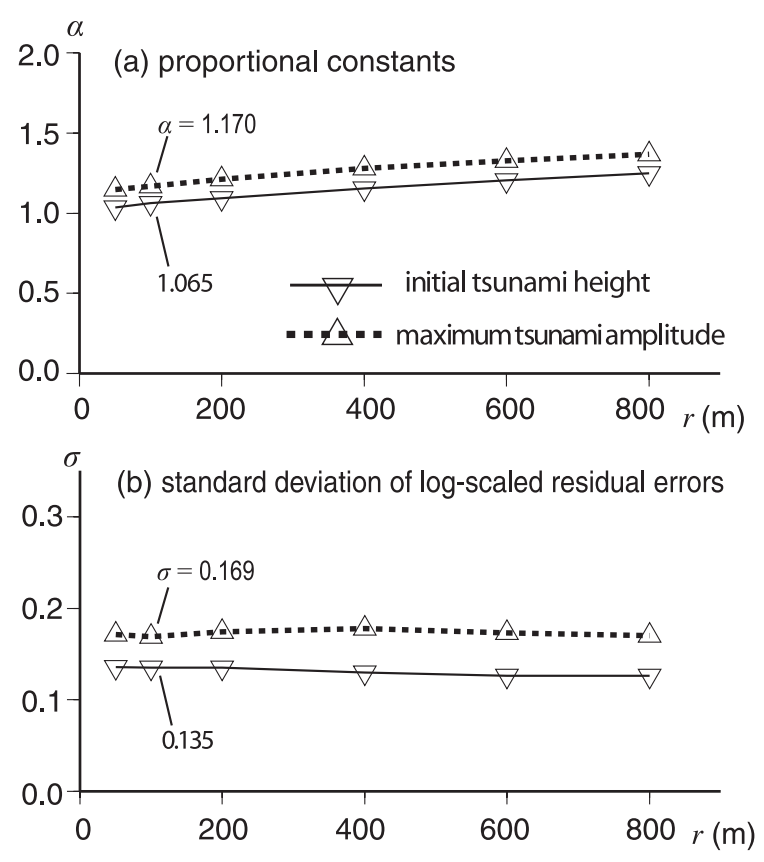

Fig. 4. Dependency of the proportional constants and the standard deviation of the $\log$-scaled residual errors to the parameter $r$. The depth at a coastal station was defined as the average depth within $r$ from the station along the waterway (see Section 3). (a) The relationship between $r$ and $\alpha$ (Eq. (4)) is plotted. (b) The relationship between $r$ and standard deviation of residual error of $\log _{10} H_{\mathrm{c}}$ is plotted. Residual errors are measured by the difference of $\log _{10} H_{\mathrm{c}}$ between by the coastal observation data and the calculated values by regression functions (Eqs. (6) and (7)). differences between maximum and minimum of $\sigma$ for the tested range of $r$ are 0.010 for initial tsunami height and 0.008 for maximum tsunami height (Fig. 4(b)). Such a small dependency of $\sigma$ on $r$ means that the expected accuracy of the experimental equations relating offshore and coastal tsunami height are almost same as long as the $r$ is in the tested range $(50 \mathrm{~m} \leq r \leq 800 \mathrm{~m})$. Therefore, the $r=100 \mathrm{~m}$ employed in this study is good enough to define depth at a coastal site.

\subsection{Application to tsunami data by RTK-GPS buoys}

RTK-GPS buoys have to date sampled only two tsunami events for which they have recorded data with sufficient clarity to use in a discussion of tsunami height: the 2003 Tokachi-oki earthquake tsunami at the Off Muroto GPS buoy, which is $2 \mathrm{~km}$ off the coast (Nagai and Ogawa, 2004), and the 2004 earthquake tsunami off Kii peninsula at the Off Muroto GPS buoy, which is $13 \mathrm{~km}$ off the coast (Kato et al., 2005; Nagai and Satomi, 2005). Although RTK-GPS buoys are generally installed further offshore than NOWPHAS wave stations, as indicated in Fig. 3, tsunami data obtained by these two systems seem to fit the same regression lines for correcting both the initial tsunami height and maximum amplitude data recorded by the RTK-GPS buoys. This correlation suggests that Eqs. (6) and (7) can be used to correct tsunami observation data recorded not only by NOWPHAS wave stations but also by RTK-GPS buoys, with the aim of comparing or predicting initial tsunami heights or maximum tsunami amplitudes at nearby tidal stations. If the initial tsunami height from RTK-GPS buoys can be detected in real-time, the real-time application of Eq. (6) enables us to forecast initial tsunami height at the nearby coast. Such an advanced tsunami forecast may probably be achieved in the near future because RTK-GPS buoys have been adopted as a new sensor for NOWPHAS and have been installed gradually since 2007 .

\section{Summary}

Initial tsunami height and maximum tsunami amplitude data obtained by coastal tidal stations and offshore sites of NOWPHAS wave stations or RTK-GPS buoys (Fig. 1; Table 1) were retrieved from technical reports published by PARI or JMA (Table 3). Pairs of tsunami data observed at offshore observatories and nearby coastal stations during eight tsunami events (Tables 2 and 3) were compared (Section 3). The ratio of initial tsunami height or maximum amplitude observed at a coastal tidal station to that at the offshore site was found to be proportional to the fourth root of the ratio of the sea-bottom depths from the mean sea level at the offshore sites to the coastal station (Eqs. (6), (7); Fig. 3). Based on the standard deviations of the log-scaled residual errors (Fig. 4(b)) of Eqs. (6) and (7), differences between the initial tsunami height or maximum tsunami amplitude corrected by these equations and the observed value at the nearby coastal tidal station are expected to be on the order of about 30\% (Section 4.1). If offshore NOWPHAS wave stations or RTK-GPS buoys successfully detect initial tsunami height in real time, the relationship (Eq. (6)) derived in this paper enables us to realize real-time forecasting of initial tsunami height at a nearby coast with high accuracy. 
Acknowledgments. Thanks are due to three anonymous reviewers for their valuable comments and helpful suggestions. This work was supported in part by Japan Society for the Promotion of Science (Grant-in-Aid for Scientific Research No. 20510173). Some of the figures were prepared using the Generic Mapping Tools (Wessel and Smith, 1998). I gratefully acknowledge helpful discussions with Dr. K. Hirata (Meteorological Research Institute), Mr. Y. Hasegawa, Mr. Y. Nishimae, and Mr. K. Nakata (Japan Meteorological Agency) on several points in the paper.

\section{References}

Baba, T., K. Hirata, and Y. Kaneda, Tsunami magnitude determined from ocean-bottom pressure gauge data around Japan, Geophys. Res. Lett., 31, L08303, doi:10.1029/2003GL019397, 2004.

González, F. I., E. N. Bernard, C. Meinig, M. C. Eble, H. O. Mofjeld, and S. Stalin, The NTHMP tsunameter network, Nat. Hazards, 35, 25-39, doi:10.1007/s11069-004-2402-4, 2005.

Gower, J., Jason 1 Detects the 26 December 2004 Tsunami, Eos Trans. $A G U$, 86, 37-38, 2005.

Headquarters for Earthquake Research Promotion, The next Promotion of Earthquake Research-Comprehensive Basic Policies for the Promotion of Earthquake Research through the Observation, Survey, and Research-, 23p, 2009 (in Japanese).

Japan Meteorological Agency, Tidal Observations, Ser. 6 no. 1, 2, and 4, 1994, 1995, 1997.

Japan Meteorological Agency, The Annual Seismological Bulletin of Japan for 2007, CD-ROM, 2008.

Kato, T., Y. Terada, M. Kinoshita, H. Kakimoto, H. Isshiki, M. Matsuishi, A. Yokoyama, and T. Tanno, Real-time observation of tsunami by RTKGPS, Earth Planets Space, 52, 841-845, 2000.

Kato, T., Y. Terada, K. Ito, R. Hattori, T. Abe, T. Miyake, S. Koshimura, and T. Nagai, Tsunami due to the 2004 September 5 th off the Kii peninsula earthquake, Japan, recorded by a new GPS buoy, Earth Planets Space, 57, 279-301, 2005.

Kobune, K., T. Nagai, N. Hashimoto, T. Hiraishi, and K. Shimizu, Characteristics of the Irianjaya Earthquake Tsunami in 1996, Tech. Note Port Harbour Res. Inst., no. 842, 96 p, 1996 (in Japanese).

Nagai, T., Development and improvement of the Japanese coastal wave observation network (NOWPHAS), J. Jap. Soc. Civil Eng., no. 609 (VI41), 1-14, 1998 (in Japanese).
Nagai, T. and H. Ogawa, Characteristic of the 2003Tokachi-off Earthquake Tsunami profile, Tech. Note Port Airport Res. Inst., no. 1070, 92p, 2004 (in Japanese).

Nagai, T. and S. Satomi, Records of observed 2004 Tokaido-off Earthquake Tsunami profile, Tech. Note Port Airport Res. Inst., no. 1096, 22p, 2005 (in Japanese).

Nagai, T. and S. Satomi, Records of the observed 2005 Miyagi-Prefectureoff Earthquake Tsunami profile, Tech. Note Port Airport Res. Inst., no. 1119, 35p, 2006 (in Japanese).

Nagai, T., N. Hashimoto, T. Hiraishi, and K. Shimizu, Characteristics of the Hokkaido-East-Off-Earthquake Tsunami, Tech. Note Port Harbour Res. Inst., no. 802, 97p, 1995 (in Japanese).

Okal, E. A., A. Piatanesi, and P. Heinrich, Tsunami detection by satellite altimetry, J. Geophys. Res., 104, 599-615, 1999.

Seismology and Volcanology Research Division, Meteorological Research Institute, Permanent Ocean-Bottom Seismograph Observation System, Tech. Rep. Meteorol. Res. Inst., no. 4, 233p, 1980 (in Japanese).

Shimizu, K., M. Sasaki, and T. Nagai, Characteristic of the 2006 ChishimaIslands-off Earthquake Tsunami profile, Tech. Note Port Airport Res. Inst., no. 1162, 83p, 2007 (in Japanese).

Takayama, H., Statistical relationship between tsunami maximum amplitudes of offshore and coastal stations, Pap. Meteor. Geophys., 59,. 8395, doi:10.2467/mripapers.59.83, 2008 (in Japanese).

Takayama, T., Y. Suzuki, H. Tsuruya, S. Takahashi, C. Gotoh, T. Nagai, N. Hashimoto, T. Nagao, T. Hosoyamada, K. Shimosako, K. Endo, and T. Asa, Field investigations of the tsunami caused by 1993 Hokkaido Nansei-oki Earthquake, Tech. Note Port Harbour Res. Inst., no. 775, 225p, 1994 (in Japanese).

Tatehata, H., The new tsunami warning system of the Japan Meteorological Agency, in Perspectives on tsunami hazard reduction-Observations, Theory and Planning, edited by G. Hebenstreit, 175-188, Kluner Academic Publishers, Dordrecht, 1997.

Tsushima, H., R. Hino, H. Fujimoto, Y. Tanioka, and F. Imamura, Nearfield tsunami forecasting from cabled ocean bottom pressure data, $J$. Geophys. Res., 114, B06309, doi:10.1029/2008JB005988, 2009.

Wessel, P. and W. H. F. Smith, New improved version of Generic Mapping Tools released, Eos Trans. AGU, 79, 579, 1998.

Y. Hayashi (e-mail: yhayashi@mri-jma.go.jp) 